Пронькина О.Ф., преподаватель, Городской университет г. Ланьчжоу, Китай

\title{
ШЕЛКОВЫЙ ПУТЬ КАК СИМВОЛ ПОИСКА ГАРМОНИИ ИНЬ И ЯНЬ, ЖЕНСКОГО И МУЖСКОГО (на материале романа Р. Баха «Мост через вечность»)
}

О. Пронькіна досліджує образ Шовкового шляху як символ пошуку гармонії інь $і$ янь, Сходу i Заходу, жіночого та чоловічого в романі Р. Баха «Міст через вічність». Автор пов'язана з історією иьього унікального культурного явища, вона живе і пращює в Ланьчжоу місті, який входив в географію Шовкового шляху. Ї̈ стаття являє собою спробу по-новому інтерпретувати ией образ, розглянути його як символ єднання протилежностей. Роман Р. Баха «Міст через вічність» розкриває символічне значення образу Шовкового шляху як гармонійну єдність жіночого та чоловічого, інь і янь.

Ключові слова: Схід, Захід, інь-янь, образ, роман, символ, Шовковий илях. 
О. Пронькина исследует образ Шелкового пути как символ поиска гармонии инь и янь, Востока и Запада, женского и мужского в романе Р. Баха «Мост через вечность». Автор связана с историей этого уникального культурного явления, она живет и работает в Ланьчжоу - городе, который входил в географию Шелкового пути. Ее статья представляет собой попытку по-новому интерпретировать этот образ, рассмотреть его как символ единения противоположностей. Роман Р. Баха «Мост через вечность» раскрывает символическое значение образа Шелкового пути как гармоническое единство женского и мужского, инь и янь.

Ключевые слова: Восток, Запад, инь-янь, образ, роман, символ, Шелковый путь.

Исследует образ Шелкового пути. Шелковый путь - символ соединения инь и янь, мужчины и женшцины, Востока и Запада. Роман Р. Баха «Мост через вечность» показывает, что на Шелковом пути жизни человек ищет себя, любовь, свою часть. Автор считает, что родственные души - одно целое, гармония инь и янь, Запада и Востока, женского и мужского, вечного и изменчивого; они находят смысл жизни только рядом друг с другом.

Pronkina Olga (奥莉娅, 兰州城市学院), Lanzhou City University discovers symbolism of the Great Silk Road. It is a symbol of unification of Yin and Yang, Male and Female, West and East. $R$. Bach's Novel "Bridge though the infinity» shows, that being on the Silk Road person try to find himself, his love and his second half. Richard thought, that soul mates are united in a harmony of Yin and yang, West and East, Male and Female, Infinite and Changeable, they are both find a sense of life, only being together with each other.

Key words: thought, literature study, worldview, poetics, psychological, cognitive, novels, characters

Шелковый путь (丝绸之路) в истории человечества, безусловно, стал символом единения Востока и Запада в самых разных жизненных ипостасях: экономических, культурных, просветительских, философских, религиозных. Исторические хроники свидетельствуют о том, что это уникальное явление возникло еще во втором веке до н. э.; путь проходил через китайские регионы Сиань (西安), Ланьчжоу (兰州), Дуньхуан (敦煌), затем в Турфан (吐鲁番), Памир, Фергану, Лоб-Нор, Бактрию, Индию, эллинские города. Подлинное значение Шелкового пути и сегодня трудно оценить в полной мере, поскольку многие мировые культуры до сих пор несут в себе отпечатки взаимодействия с цивилизацией Востока. Важно подчеркнуть, что по Шелковому пути распространялись основные мировые религии: буддизм, христианство, ислам, которые в ряде стран переплетались в синтетическое религиозно-философское мировоззрение.

На наш взгляд, уникальность Шелкового пути позволяет рассматривать его не только как историческое явление, но так же, как некий духовный опыт, запечатленный в произведениях искусства. Не случайно древние китайские 
трактаты содержат символическое изображение сплетенных белого тигра (инь, женщина, Запад) и зеленого дракона (янь, мужчина, Восток). Мы считаем, что есть все основания увидеть в Шелковом пути не только традиционный символ поиска точек соприкосновения между Востоком и Западом, но, в первую очередь, поиск единства женского и мужского начал, инь и янь, жизненного пути, морально-этических ориентиров, поиска самого себя. Поэтому в данной статье мы ставим перед собой цель рассмотреть Шелковый путь как символ поиска единства мужского и женского в романе Р. Баха «Мост через вечность».

Для понимания авторской концепции целесообразно увидеть истоки понятия родственной души. Идея родственной души в искусстве не нова, она основывается на мифе, рассказанном еще Платоном о том, что в древнем мире жили люди трех полов, причем третий пол носил признаки как мужского, так и женского начал. Зевс, чтобы уменьшить их силу, предложил разделить каждого из них. Так появились на земле половинки тел и душ, инь и янь. Согласно другим теориям теософии, Бог создал двуполые души, которые позже разделились на две части, и с тех пор половинки находятся в поиске друг друга. Они идут по Шелковому пути, чтобы в конце концов стать целым, найти свою частичку янь или инь. Эта легенда положена в основу многих романов Р. Баха. Автор считает, что родственная душа никогда не пройдет мимо нас, но, встретив, нужно суметь удержать ее, ведь человек не только ответственен за свою судьбу, но и способен управлять ею.

Впервые к концепции родственной души Бах обратился в произведении «Мост через вечность» («The Bridge Across Forever: A Love Story») (1977). Роман представляет собой трогательный рассказ о понимании собственной души, которая, как Шелковый путь, сочетает мужское и женское. Герой Ричард (очевидно, alter ego-автора) годами терпеливо ждал женщину своей мечты, идеальную спутницу жизни. Герой встречает Лесли. С ней Ричард начинает свое магическое путешествие-поиск собственной жизни, который словно олицетворяет собой духовный Шелковый путь героя. Вместе с Лесли он с готовностью исследует все стороны столкновения двух людей: обязанность и 
долг, наслаждение и удовольствие, ответственность. В этом автобиографическом романе автор, пытаясь решить проблему родственных душ, показывает, что все существо героя, вся его жизнь направленные на решение постоянно волнующего Баха вопроса - где на жизненном Шелковом пути найти родственную душу? Этот поиск становится главной целью героя Ричарда, центральной недостающим звеном его самореализации. Без родственной души для него невозможно ощущение жизненной целостности и гармонии.

Центральной темой художественного произведения становится тема любви совместного жизненного Шелкового пути героев (Ричарда Баха - alter ego-автора - и Лесли Пэриш). Проблематика произведения основывается на противопоставлении факта существования родственной души и реальными возможностями ее поиска. Одновременно в произведении раскрыты бытовое материальное благополучие, вопрос личности и еe самореализации, психологическая совместимость и возможность сосуществования родственных душ. Бах показал значение родства душ, судьбы человека, который, найдя свою половину, является «мостом через вечность», проводником и источником знаний о любви, единой, неизменной и постоянной.

Система основных событий охватывает описание жизни героя, его Шелкового пути в целенаправленном, упорном поиске родственной души, а также знакомстве с Лесли Пэрриш и жизни с нею. Сюжет произведения характеризуется адинамичнистю, действие развивается замедленно, не стремится к развязке, Бах описывает период поиска родной души, а также охватывает все события жизни в тот период. Все они имеют второстепенное значение, но так или иначе помогают раскрыть образ и характер героя.

В прологе автор эмоционально настраивает читателя на восприятие романа, создавая атмосферу сказки: «Порой нам кажется, что не осталось на земле ни одного дракона. Ни одного храброго рыцаря, ни единой принцессы, пробирающейся тайным лесными тропами, очаровывая своей улыбкой бабочек и оленей» [Бах 2001:1], - так начинает свое произведение автор, показывая 
романтическую направленность и невероятное, сверхъестественное существование непостижимых законов реальной жизни. К таким законам и относятся неизбежность встречи с родственной душой на жизненном Шелковом пути, предназначенном судьбой. Пролог также определяет отношение автора рассказа к любовной романтической истории, создающий таким образом лирическую тональную систему романа. Главной же функцией пролога произведения является открытие ключевой идеи произведения, объяснения авторского отношения к теме любви и проблеме родственной души: «Нам кажется, что наш век отделяет от тех сказочных времен какая-то граница, и в нем имеется места приключения ... это не так! ... Интуиция нашептыввает истину: мы не пьль, мы - волшебство!»[Бах 2001:1]. Так, Бах изображает существование сверхъестественного в жизни каждого человека, участвующего в поиске родственной души и настоящей любви на своем Шелковому пути.

Родственная душа - «милая, мудрая и таинственная прекрасная леди» [Бах 2001:2]. Свою родственную душу Ричард описывает как спокойную и рассудительную, привлекательную, c совершенным лицом, которая гармонирует с ним и телом, родная душа должна быть независимой, любить авантюры, быть творческой развитой личностью, бесстрашной, готовой рисковать, интересной и с «неуемной жаждой знаний» [Бах 2001:76]. Родственная душа, соединившая инь и янь, - это близкий человек, встретив которую, по мнению автора, не воспринимаешь внешнюю оболочку, и так совершенную, но познаешь внутренний мир дорогого нам человека.

Лесли для героя - «бестелесная фея» [Бах 2001:41]. Интеллектуальные способности родственной души человека настолько поражали Ричарда, что ему казалось, будто Лесли всегда носила с собой справочник, который отвечал на любые вопросы из разных областей искусства и общественной жизни: «У $У_{\mathcal{L}}, \boldsymbol{8}$ котором были танщевальные па, справочник по кинопродукции, классическая музыка, политика, балет» [Бах 2001:41]. Лесли обладает не только глубокими знаниями, но и ведет активную общественную деятельность, участвует в 
антивоенном движении. Важными чертами героини, составляющими ее психологический портрет как родственной души автора, являются профессиональные качества Лесли-актрисы. Пэриш мастерски владела навыками актерского мастерства, она играла в фильме, ни разу не заглянув в текст. Это привело Ричарда к мысли о том, что «происходит нечто магическое» [Бах 2001:53]. Совершенная женщина кажется Ричарду настоящей, живой личностью, лучшим другом. И это является одной из главных особенностей родственной души - она не только любимая, решительная, привлекательная, но еще и настоящий друг, который поддерживает, помогает, является духовной живительной силой. Автор изображает совершенную женщину как ангелахранителя, что, возможно, указывает на его желание быть под опекой кого-то, еще это свидетельствует о чувстве одиночества героя.

Сама Лесли характеризует Ричарда как человека, обладающего творческими способностями, эмоционально уравновешенного, честного и порядочного, который также должен быть «положительной конструктивной личностью; духовной натурой, но не принадлежать к какой-либо организованной религии. Должен любить кошек» [Бах 2001:79]. Совершенный мужчина для героини - многогранная натура, всесторонне развитая личность с многочисленными положительными качествами, талантами и склонностями. Возможно, эти характеристики раскрывают авторское представление о самом себе, помогают понять его психологию.

Образ Ричарда достаточно противоречивый и сложный, очень часто он совершает негативные и отрицательные поступки. Внутренние монологи героя наполнены самоанализом, также свидетельствует о его нерешительности и противоречивости. Ричард сам не всегда ясно представляет свою родственную душу, Шелковый путь к ней, искусство общения и взаимопонимания. «Она вылуманная тобой, - описывает Бах родственную душу, - утыканная поддельным перьями всевозможных изветов курица весом с полтонны, которой никогда не взлететь! Все, что она может, - это бегать туда-сюда, хлопать крыльями и пронзительно кудахтать, но никогда, никогда Она не сможет 
оторваться от земли, никогда не сможет запеть» [Бах 2001:117]. Одной из ярких черт характера героя и одновременно источником конфликтов в романе является его принципиальность по отношению к собственной свободе и независимости. Ричард готов расстаться с родственной душой, только бы не связывать себя узами ответственности. Так, для того, чтобы доказать свое незыблемое право на свободу, герой на просьбу Лесли помочь ей во время болезни, решает провести время с другой женщиной Деборой, потому что убежден: «Mbl свободны проводить время с тем, кого выбираем» [Бах 2001:113]. Автор показывает, что для него более важны личные отношения, чем обязательства и внимание в дружбе.

Безусловно, что родственная душа, а также долгожданная встреча с ней тождественны поиску и пониманию любви в произведении. Ричард ищет родственную душу, но также ищет любовь. И вот любовь приносит успокоение, наслаждение, невероятное для героя счастья. «Мне сейчас умирать от счастья, или немного погодя?», - спрашивает себя Ричард [Бах 2001:73]. Любовь в романе сравнивается со светом, который олицетворяет собой грандиозное, всепоглощающее чувство, такое сильное, что «что сама идея о силе кажется смешным перышки мысли» [Бах 2001:72].

Таким образом, родственная душа не только та, которая полностью соответствует потребностям человека, но и та, ради которой и с которой человек готов бороться, спорить. Это столкновение двух родственных душ на Шелковом пути жизни в результате приводит к пониманию совершенного общения и гармонии инь и янь. Все достигается путем развития, изменения, роста и личностной победы над собой. Поиск такой души Бах называет главным в жизни. Кроме того любовь дает свободолюбивому Ричарду настоящее, глубокое чувство внутренней свободы. И вместе со свободой родственная душа открывает ему настоящий Шелковый путь к осознанию смысла жизни, своего места, а также дает новую, другую жизнь. Автор подводит читателя к раскрытию ключевой идеи романа: родственные души, находя друг друга, вместе становятся мостом через вечность, на Шелковом 
пути, который возвышается над «морем времени, где мы радуемся приключениям, забавляемся живыми тайнами, выбираем себе катастрофы, триумфы, свершения, невообразимые прочсшествия, проверяя себя снова и снова, обучаясь любви, любви и любви!» [Бах 2001:182]. Родственные души одно целое, гармония инь и янь, Запада и Востока, женского и мужского, вечного и изменчивого; они находят смысл жизни только рядом друг с другом.

\section{БИБЛИОРГАФИЯ}

Бах 2001 - Бах Р. Мост через вечность/ Ричард Бах; / пер. с англ. И. Старых, А. Мищенко. - К. : София, 2001. - 367 с. 